\title{
Demographic Changes in Russia - Past and Future
}

\author{
ANATOLY VISHNEVSKY, Ph.D. \\ Centre for Demography and Human Ecology \\ Institute for Economic Forecasting, \\ Russian Academy of Sciences \\ Moscow
}

\section{Abstract}

Many important demographic indices have changed dramatically in Russia during the last 10 years. The total fertility rate decreased from 2.20 to 1.28 between 1987 and 1996 . The life expectancy for males fell by more than 7 years between 1987 and 1994, and for females by more than 3 years; after this, life expectancy began to rise again, but by 1997 the loss for males was restored by only $45 \%$ and for females by $60 \%$. The natural increase of population became negative in 1992 and despite positive net migration the population of Russia began to decline. During 1992-1997 it decreased by 1.6 million persons. The population decline will continue and, according to varying forecasts, the total losses can reach from 2.4 to 12.8 million persons by 2010 .

What all this means is that Russia is experiencing a serious demographic crisis. There are different constituent elements behind this crisis requiring different reactions from society. Fertility in Russia fell below replacement level several decades ago and hence the emergence of a negative natural population increase was unavoidable. Its emergence, which was predicted by population forecasts elaborated in the 1980s, was only slightly accelerated by the sharp fertility decline in the 1990s. But a decline in fertility to a very low level in the 1990s was typical for many European countries and not a specifically Russian phenomenon. Nowhere can the fluctuations of political or economic conditions be used to explain the decline. None of the European countries have found effective measures of raising fertility.

On the contrary, with respect to the level of mortality and its trends, Russia is in a very poor position compared to all the Western industrial countries. A rise in mortality is entirely uncharacteristic of them. The unfavorable differences regarding Russia are long-term and also cannot be properly explained by the political or economic conditions of the 1990s: this situation only aggravated the long-term Russian mortality crisis building up since the mid-60s. Judging by the most recent trends, the period of aggravation is over but the long-term crisis continues and the prerequisites for overcoming this crisis are not in place. 
The growth, or at least the stabilization, of the size of the Russian population during the first decades of the 21st century will be possible only on the condition that net migration be positive for Russia and of significant proportion. But taking into consideration economic and political realities, it is unlikely that this condition will be realized. It is more probable that the size of the Russian population will decline.

Keywords: Fertility, life expectancy, mortality, population, Russia

\section{Introduction}

The recent demographic trends in post-Soviet Russia have deeproots in the Russian history of the 20th century and can be interpreted in the context of the modernization of Russian society during this period. Demographic modernization is an important aspect of general modernization. The rapid destruction of the peasant society starting in the late 1920 s, as well as mass rural-urban migration, resulted in a break with traditional demographic behavior and in an accelerated demographic transition. The demographic evolution in Russia was almost the same as in Europe or North America but with a delay and with certain significant special features. In spite of rapid modernization, the demographic behavior of a large part of the population continued to display archaic features and, as a consequence, for a long time the level of fertility and mortality in Russia was higher and the population younger than in the West.

Nevertheless, the postwar decades became a period of increased convergence in the demographic evolution across Russia and the West. This is confirmed by the various indicators of family size and composition, family cycle, nuptiality, divorces, fertility, causes of death structure, emigration-immigration correlation, etc.

In the early 1990 s Russia arrived at a turning point in her demographic evolution. The depopulation which had taken place up to this period in its latent form became evident, and the rate of natural population increase became negative. Though this situation is a result of a long-run and, by and large, normal evolution, in actual political circumstances public opinion misapprehends it as something disastrous. Voices have been raised announcing "a demographic catastrophe", "a demographic tragedy", "the extinction of the Russian people" and so on. The negative opinions concerning the changes in the demographic sphere are exploited by anti-reformists who consider these changes to be nothing but unfavorable consequences of unneeded or unsuccessful reforms.

In actual fact, if some "catastrophic" features are present in the demographic development of Russia, they are likely to be due precisely to a delay in implementing reforms, for example, reform of the health care system. This delay hampers adaptation of social institutions to the new realities of demographic and family behavior. But these realities themselves are the natural consequence of a contradictory, delayed reaction, Russian/Soviet-style modernization. 
This modernization has constantly created and is still creating an inner resistance, but ultimately steady progress is being made. As this takes place, existing problems are solved, but new ones arise. While the new demographic realities are making their way in Russia, the country is facing the same challenges as most industrial nations (danger of depopulation, population aging, fragility of families, etc.). Since it is not possible to avoid them, Russia needs to find adequate answers to these challenges.

\section{Fertility}

Long-term trends. Pre-Revolutionary Russia stood out as having a very high level of fertility in comparison with the other countries. After a certain reduction which was the result of the shocks of World War I, the Revolution and the Civil War, the previously high level was restored for a while. From the late 1920s, fertility declined rapidly due to the broadening of the scope of procreative choice, on the one hand, and to the difficult, sometimes even catastrophic, social and political conditions of the 1930 s and 1940 s, on the other. It was not understood in the USSR. Using the general fertility rate to assess the fertility level, the Soviet official sources cited this supposedly high fertility as an example of the advantages inherent to a socialist society.

Later on, the decline in fertility, being a natural consequence of the demographic transition, still persisted. For several decades in the middle of the 20th century, Russia followed the path already traversed by the Western countries. Russia did it at an accelerated pace, and in the 1970s attained the same fertility level as many of the Western countries. But the trajectories of the fertility decline in Russia (as everywhere in Eastern Europe) and in the Western countries were different throughout the recent decades. The fertility in the two parts of Europe decreased in waves and the phases of these waves did not coincide (Figure 1).

Recent fertility decline. As Figure 1 shows, the decline of the total fertility rate in Russia after 1987 was extremely rapid. Public opinion has a tendency to attribute such an unprecedented decline to the direct influence of the social and economic crisis of the 90 s. However, even if such an influence does exist, it is not alone determining the phenomenon of fertility decline but acts together with other, perhaps much more important factors.

The fertility decline is due, among others, to the timing effects which became apparent in the 1980s. Against the background of general European trends the rise of fertility in Russia (as well as in the other former Soviet republics) in this period looks artificial. There is a very high probability that the "transversal" fertility indices increased due to the conjuncture factors (particularly due to pronatalist policy measures in the early 1980s), but this did not lead to the corresponding growth of the "longitudinal" indices. The age at which women gave birth to the "planned" children shifted, but it did not lead to an increase in the average number of births per woman in different female cohorts. Consequently, the period of increase in the total fertility rate was bound to be followed by a period of decline. In all likelihood, this was indeed the case in the late 1980 s and early 1990 s. 
Figure 1. Total fertility rate in Russia and selected Western countries

\section{Total Fertility Rate}

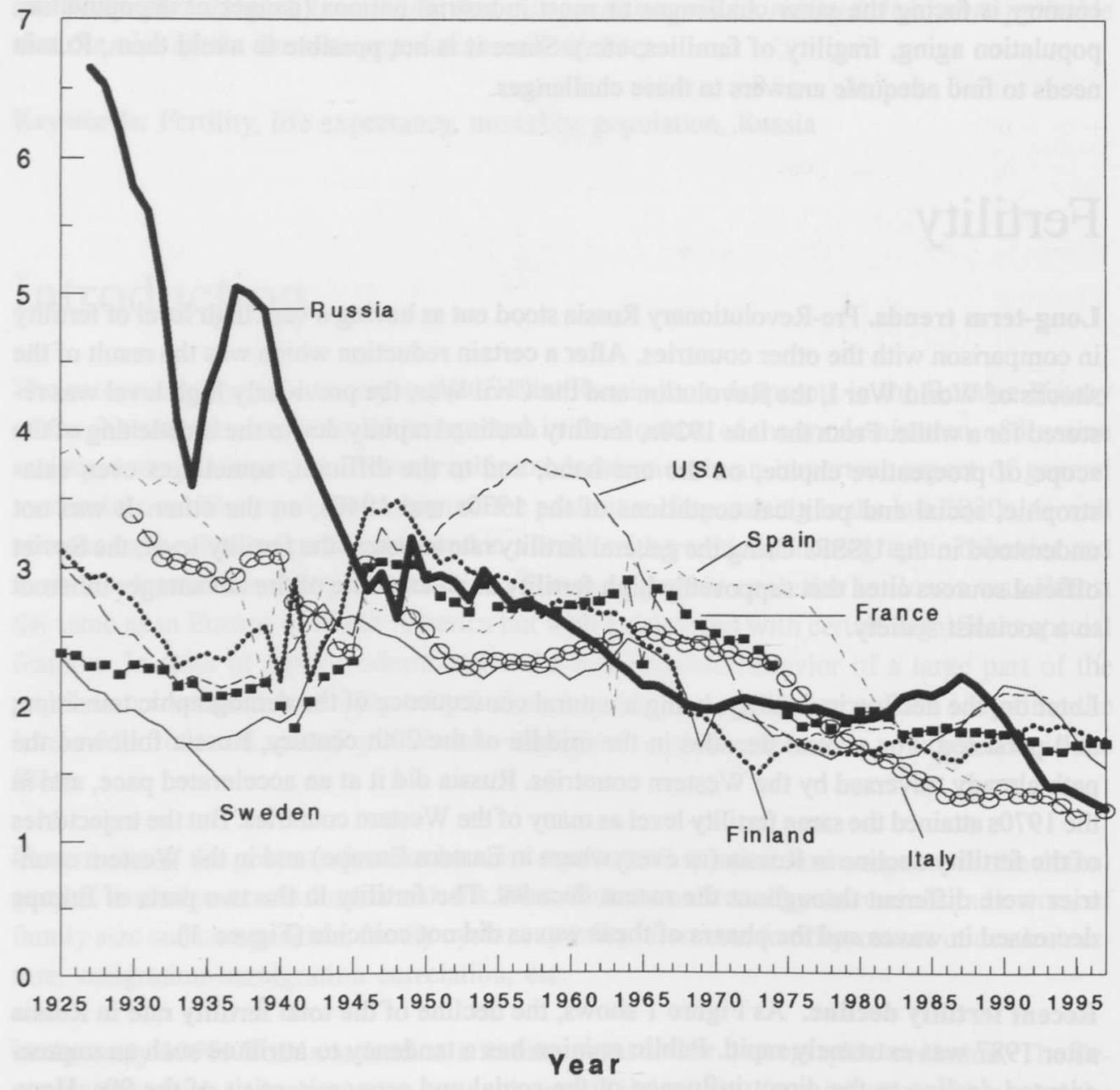

Moreover, the timing effects were accompanied by other factors which did exist before but became more visible under the influence of reforms carried out in Russia. The paternalisticstate mechanisms regulating people's economic, social and demographic behavior had weakened, opening the way to market mechanisms. That is why a great number of families are obliged to adapt their current plans to the new conditions, while extending their material and ideological capabilities for such an adaptation. In terms of demographic behavior, Russia is drawing closer to the countries with market economies. The actual total fertility rate is perceived in Russia as disastrous; it is very low, but no lower than in Germany, Italy or Spain. Not one of these countries can explain its low fertility with acute political or economic crises, instead they, and Russia, need to look for other, more profound and complicated explanations.

The level of fertility is a very important criterion of the convergence of procreative behavior in Russia and in the West. At the same time, there are important features in the Russian model of procreative behavior still differing from those in the Western one. 
Mean age at childbearing. In contrast to the recent developments in most Western countries, the decrease in the total fertility rate in Russia was accompanied by a simultaneous decrease in the age at marriage and at birth. The mean age at first marriage decreased, and the mean age at birth, after a certain increase in the late 1980 s, resumed its decline (Figure 2). The contribution of mothers under 25 to the total fertility rate has increased from $32 \%$ in 1960 to $42 \%$ in 1970 , to $50 \%$ in 1980 , to $53 \%$ in 1990 and to $59 \%$ in 1995 . Such dynamics are typical not only for Russia, but the "juvenilation" of nuptiality and fertility can also be observed in all European post-Soviet states.

Figure 2. Mean age at childbearing in Russia and selected European countries

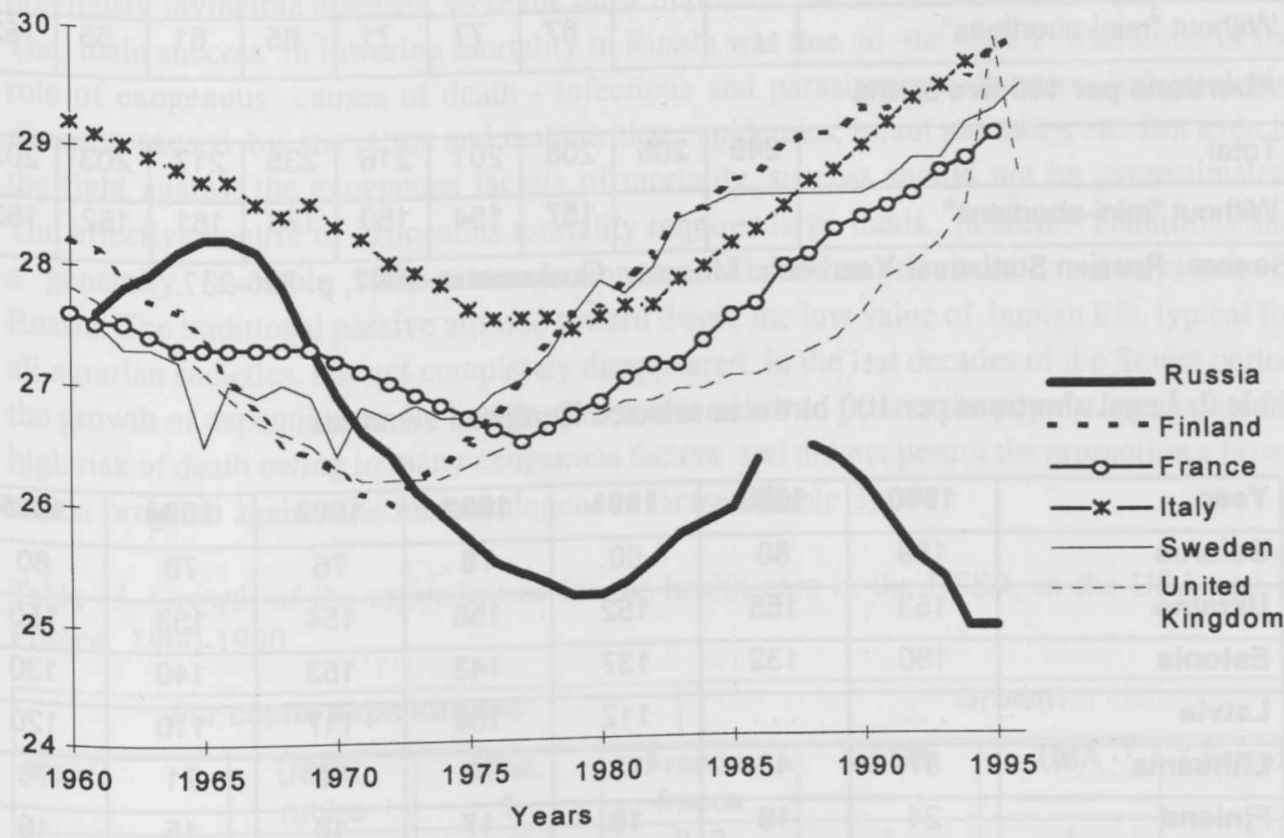

Family planning. Another important distinctive feature concerns birth control methods. In Russia, contrary to most countries that have already passed through the demographic transition, induced abortion remains one of the main methods of family planning. Although, according to official data, the absolute number of abortions and the average number per woman tended to decline during the last decade, a cautionary note is necessary because the data concerning registered abortions became increasingly incomplete for a variety of reasons. Even so, according to official figures, the proportion of conceptions ending in abortion has not diminished compared with 1980 or 1990 (Table 1).

In 1996203 abortions per 100 live births were officially registered in Russia - significantly more than in other post-Soviet states also with a very high level of abortions and much more than in Western Europe (Table 2).

Moreover, there are no signs of serious changes in the attitude of the population toward abortions. According to the results of a poll carried out by the National Centre for Study of Public Opinion (VTsIOM) in 1994, the answers to the question "What would you do in case 
Table 1. Legal abortions in Russia, 1970-1996

\begin{tabular}{|c|c|c|c|c|c|c|c|c|c|}
\hline & 1970 & 1980 & 1990 & 1991 & 1992 & 1993 & 1994 & 1995 & 1996 \\
\hline \multicolumn{10}{|c|}{ Number of abortions, thousands } \\
\hline Total & 4670 & 4506 & 4103 & 3608 & 3437 & 3244 & 3060 & 2766 & 2652 \\
\hline Without "mini-abortions" & $\cdots$ & $\cdots$ & 3128 & 2760 & 2551 & 2386 & 2266 & 2071 & 2006 \\
\hline \multicolumn{10}{|c|}{$\begin{array}{l}\text { Abortions per } 1000 \text { women } \\
\text { aged } 15-49\end{array}$} \\
\hline Total & 133 & 123 & 114 & 100 & 95 & 88 & 82 & 73 & 69 \\
\hline Without "mini-abortions" & $\cdots$ & $\cdots$ & 87 & 77 & 71 & 65 & 61 & 55 & 52 \\
\hline \multicolumn{10}{|c|}{ Abortions per 100 live births } \\
\hline Total & 245 & 205 & 206 & 201 & 216 & 235 & 217 & 203 & 203 \\
\hline Without "mini-abortions" & $\cdots$ & $\cdots$ & 157 & 154 & 160 & 173 & 161 & 152 & 153 \\
\hline
\end{tabular}

Source: Russian Statistical Yearbook. Moscow, Goskomstat, 1997, p. 236-237.

Table 2. Legal abortions per 100 births in selected European countries

\begin{tabular}{|l|c|c|c|c|c|c|c|}
\hline Year & 1980 & 1990 & 1991 & 1992 & 1993 & 1994 & 1995 \\
\hline Belarus & 189 & 80 & 80 & 78 & 76 & 78 & 80 \\
\hline Ukraine & 153 & 155 & 152 & 156 & 154 & 153 & 150 \\
\hline Estonia & 160 & 132 & 137 & 143 & 153 & 140 & 130 \\
\hline Latvia & $\ldots$ & $\ldots$ & 112 & 109 & 117 & 110 & 120 \\
\hline Lithuania & 87 & 48 & 73 & 76 & 75 & 71 & 76 \\
\hline Finland & 24 & 19 & 18 & 17 & 16 & 15 & 16 \\
\hline France & 21 & 22 & 23 & 22 & 22 & 23 & 0 \\
\hline Germany & 21 & 16 & 115 & 15 & 14 & 13 & 13 \\
\hline Italy & 32 & 28 & 28 & 26 & 26 & 26 & 26 \\
\hline United Kingdom & 22 & 25 & 24 & 23 & 24 & 24 & 24 \\
\hline
\end{tabular}

Source: Recent demographic developments in Europe 1997. Council of Europe, Strasbourg, 1997.

of unplanned pregnancy?" had the following distribution: "Would keep the baby"-13\%, "Would have an abortion" - 40\%, "Don't know " $-47 \%$. The readiness to have an abortion was the same for both urban and rural dwellers. The question appeared to be too embarrassing to $51 \%$ of the respondents claiming adherence to the Orthodox religion, and to $71 \%$ of religious Muslims; they answered, "I hardly know what to answer"1.

${ }^{1}$. Economic and Social Changes: the Public Opinion Monitoring, Moscow, 1994, 4, p. 39. 


\section{Mortality}

An incomplete epidemiological transition. Mortality is the only demographic process which really justifies the image of demographic crisis in Russia. The actual health and mortality situation of the population in Russia reflects the incompleteness of the epidemiological transition. Created by the modernization of economic and social life in the USSR, new options were used to accomplish the main tasks appropriated to the earlier stages of this transition. The achievements of medical science and the efforts of the public health care system which formulated and implemented an effective strategy of prevention and treatment of previously invincible diseases, were the most important factors behind this accomplishment. The main success in lowering mortality in Russia was due to the drastic restriction of the role of exogenous causes of death - infectious and parasitogenic diseases, tuberculosis, diseases caused by starvation and malnutrition, epidemics, infant mortality, etc. But even in the fight against the exogenous factors of mortality, success should not be overestimated. The effective control of exogenous mortality requires large funds, peaceful conditions and a generally favorable socioeconomic situation. These conditions did not always exist in Russia. The traditional passive attitude toward death, the low value of human life, typical for all agrarian societies, has not completely disappeared. In the last decades of the Soviet period the growth of expenditures for health care was too slow to protect the population against the high risk of death owing to many exogenous factors and did not permit the promotion a broad action program against the main endogenous factors (Table 3 ).

Table 3. Growth of the expenditures for the health care in the USSR, in the USA and in France, 1960-1990

\begin{tabular}{|l|c|c|c|c|c|c|}
\hline \multicolumn{4}{|c|}{ Per capita expenditures } & \multicolumn{4}{c|}{ Growth } \\
\hline Year & $\begin{array}{c}\text { USSR, } \\
\text { rubles }\end{array}$ & $\begin{array}{c}\text { USA, } \\
\$\end{array}$ & $\begin{array}{c}\text { France, } \\
\text { francs }\end{array}$ & USSR & USA & France \\
\hline 1960 & 27 & 143 & 242 & 1 & 1 & 1 \\
\hline 1970 & 49 & 346 & 816 & 1.8 & 2.4 & 3.4 \\
\hline 1980 & 72 & 1064 & 3566 & 2.7 & 7.4 & 14.7 \\
\hline 1990 & 124 & 2601 & 9521 & 4.7 & 18.2 & 39.3 \\
\hline
\end{tabular}

Sources: National economy of the USSR, different years; Statistical Abstract of the United States 1994. U.S. Department of Commerce. Bureau of the Census, Washington, 1994, p. 109; Annuaire rétrospective de la France. Séries longues. 1948-1988, p. 190; Annuaire statistique de la France 1994. Institut national de la statistique et des études, Paris, p. 241.

Finally, on one hand, the main tasks of the earlier stages of the epidemiological transition in Russia have not been carried out in full, and the exogenous factors continue to be of great significance. On the other hand, the tasks emerging with the completion of the epidemiological transition are being tackled in an unsatisfactorally: the control of endogenous factors of mortality is not effective. Both of these aspects portraying how in complete the epidemiological transition in Russia has been are determinants of the long-term crisis in mortality. 
Life expectancy: the long-term trends. The most familiar manifestation of the Russian mortality crisis is a long-term stagnation or deterioration of life expectancy.

After World War II, the level of mortality in Russia decreased quite rapidly and life expectancy grew, approaching levels comparable to those of major industrial countries. In the mid1960s, the gap between life expectancy in Russia and in the Western countries reached its smallest point. This trend soon changed. Life expectancy in Russia stagnated and even declined, and the gap between Russia and the majority of the industrial countries widened again (Figure 3).

The anti-alcohol campaign that was launched in 1985 briefly managed to reverse this decline. In 1987, life expectancy at birth reached its highest level in the history of Russia: 65 years for men and 74.6 years for women. By 1988 , however, the trend reversed once again and in the early 1990s Russia saw an unprecedented increase in mortality. The sharpest change occurred in 1993 when life expectancy decreased by 3.1 years for men and 1.6 years for women. By 1994, life expectancy had fallen to 57.4 years for men and 71.0 years for women. Since 1995 mortality in Russia declined again and life expectancy grew to 61 years for men and 73.1 years for women in 1997. Although the level of mortality continues to fall, in 1997 it was at its highest point for males since the end of the 1950s and for females since the late 1970s (female life expectancy was 73 years in 1975-1976 and 1979-1980 and 73.1 years in 1976-1977, 1978-1979 and 1980-1981).

On the whole, with the exception of the years 1985-1987, the period between the mid-1960s and the mid-1990s has been characterized in Russia by negative trends in mortality and life expectancy. During this same period, life expectancy in most industrial countries has grown, leaving Russia catastrophically far behind (Figure 3). Thus, it may be said that Russia has been experiencing a prolonged mortality crisis for the past three decades.

Age-specific patterns in the recent mortality evolution. The ups and downs in mortality during the early and mid-1990s were not homogenous. They did not concern every age group. In practice, children did not experience an increase in mortality. The infant mortality rate (17.4 deaths per 1,000 live births in 1996) is now lower then ever in Russia, although it is three times greater than the average in the European Union and four times greater than in Japan. The mortality of elderly persons over 75 years of age has risen, but not so much, and now the mortality rate of elderly men in certain ages is even lower than before the mortality increase of the early 90s. The main victim of this increase was the adult population aged between 30 and 60 years, especially males. The subsequent decline of mortality also affected these age groups but it has not yet been sufficient to restore the level of 1991 (see Figure 4).

Causes of death. Understanding of the Russian mortality crisis can be deepened with an analysis of the causes of death. Since the 1960s Russia clearly has failed in the modern stage of the epidemiological transition and, in fact, the archaic structure of mortality by causes of death stagnated and even began to worsen. Unlike the progressive changes in the industrialized world in the second half of the 20th century, the long-term trends in Russia have in many cases taken the opposite direction. 
Figure 3. Life expectancy in Russia and selected European countries, 1970-1996

Life expectancy, years

Males

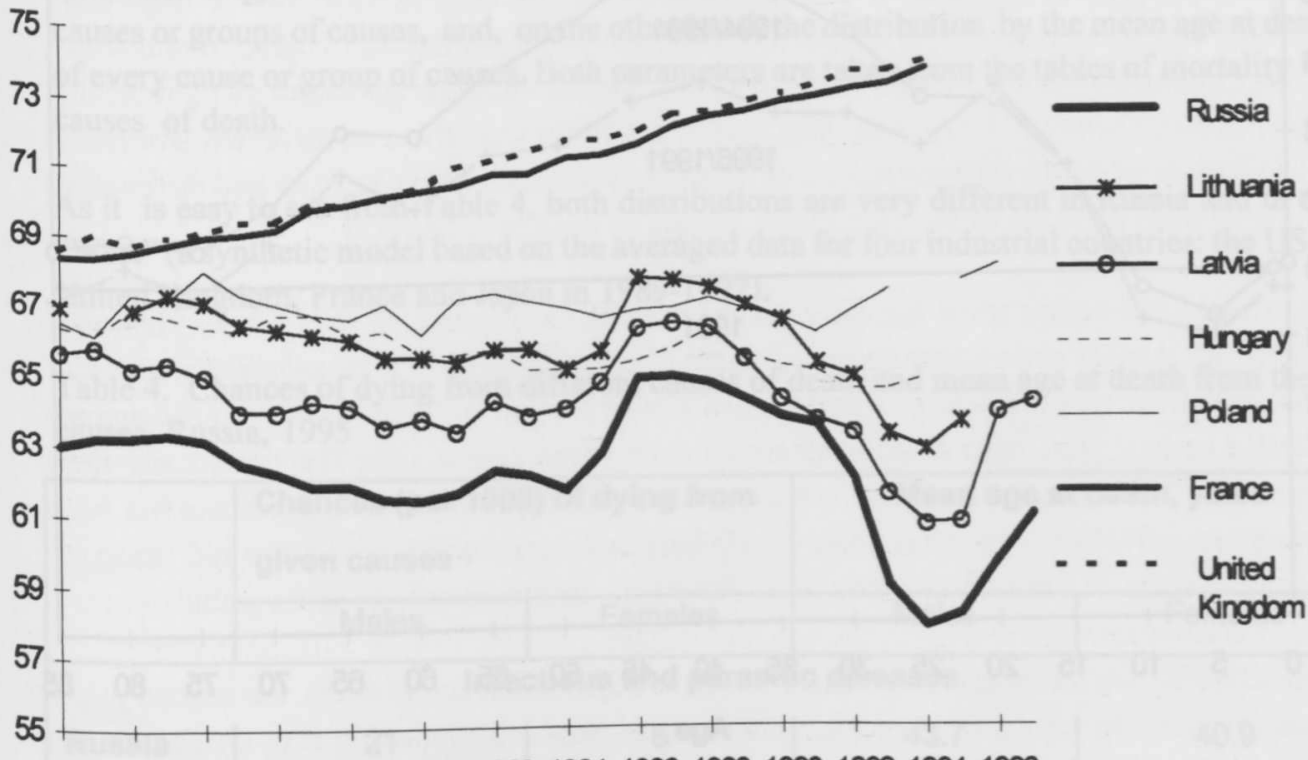

19701972197419761978198019821984198619881990199219941996

\section{Years}

Life expectancy, years

\section{Females}

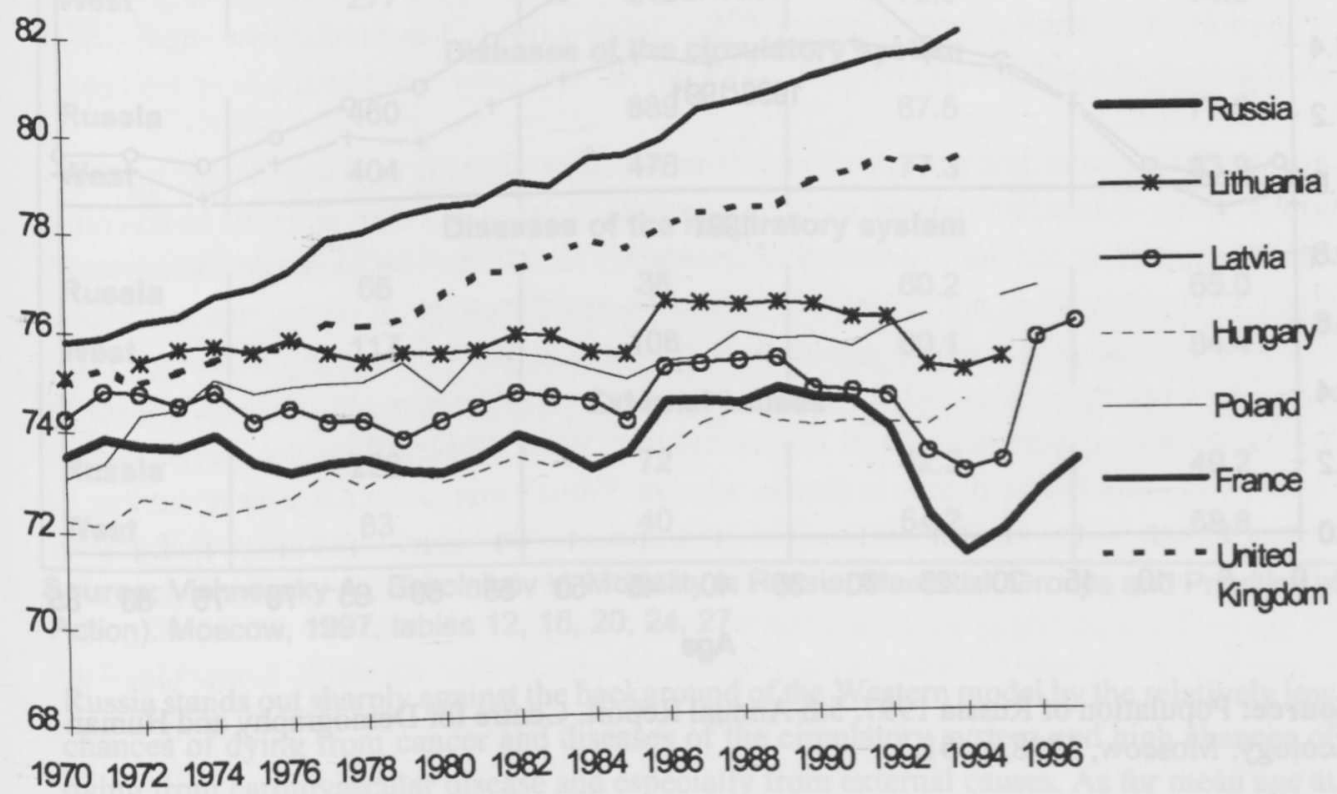

\section{Years}

Source: Hertriche V. and F. Meslé. Mortality by cause in the Baltic countries since 1970: A method for reconstructing time series. Revue Baltique, Vilnus, 1997, No. 10. 
Figure 4. Age-specific mortality rates in 1994 and 1996 in comparison with 1991

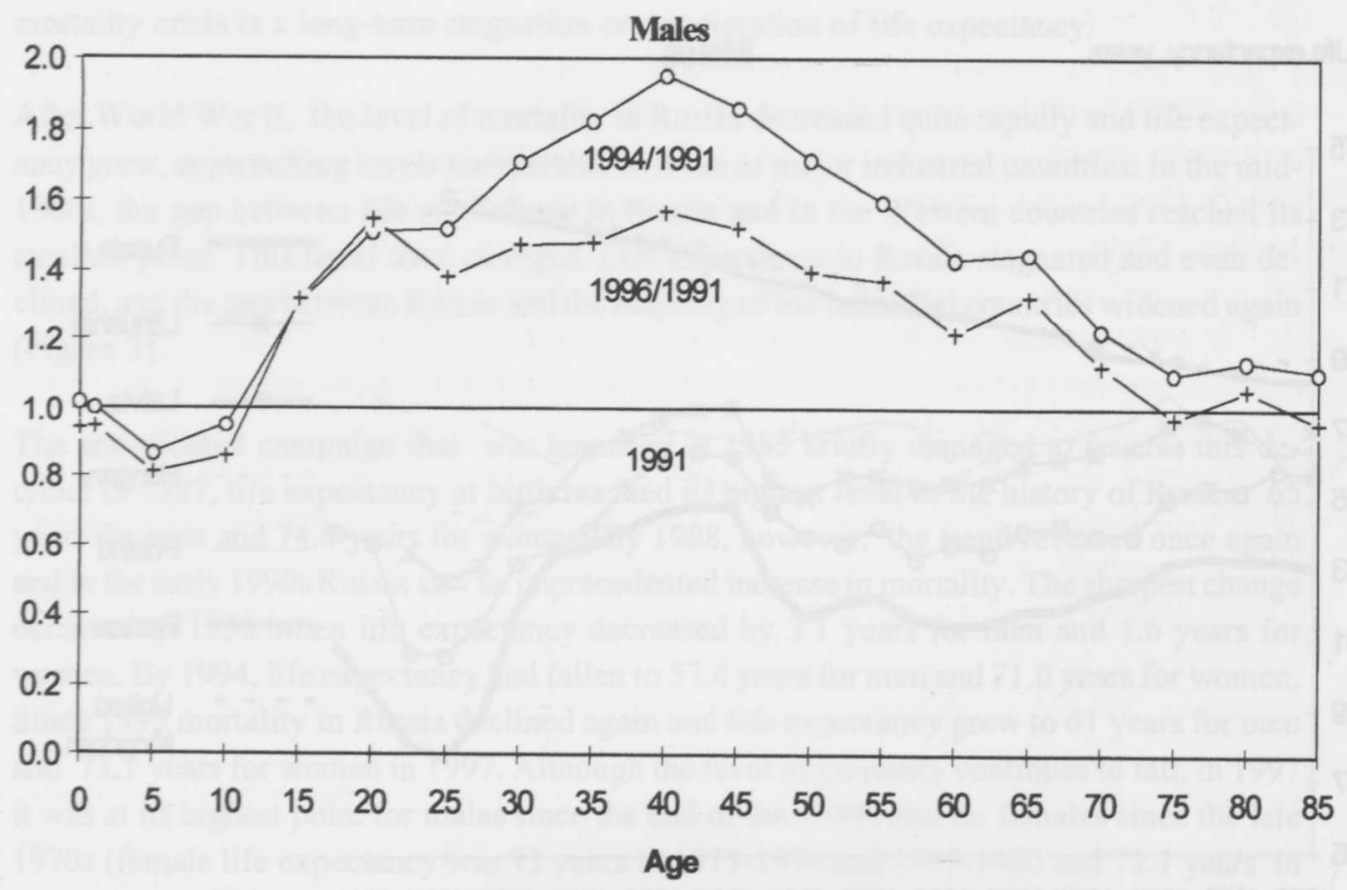

Females

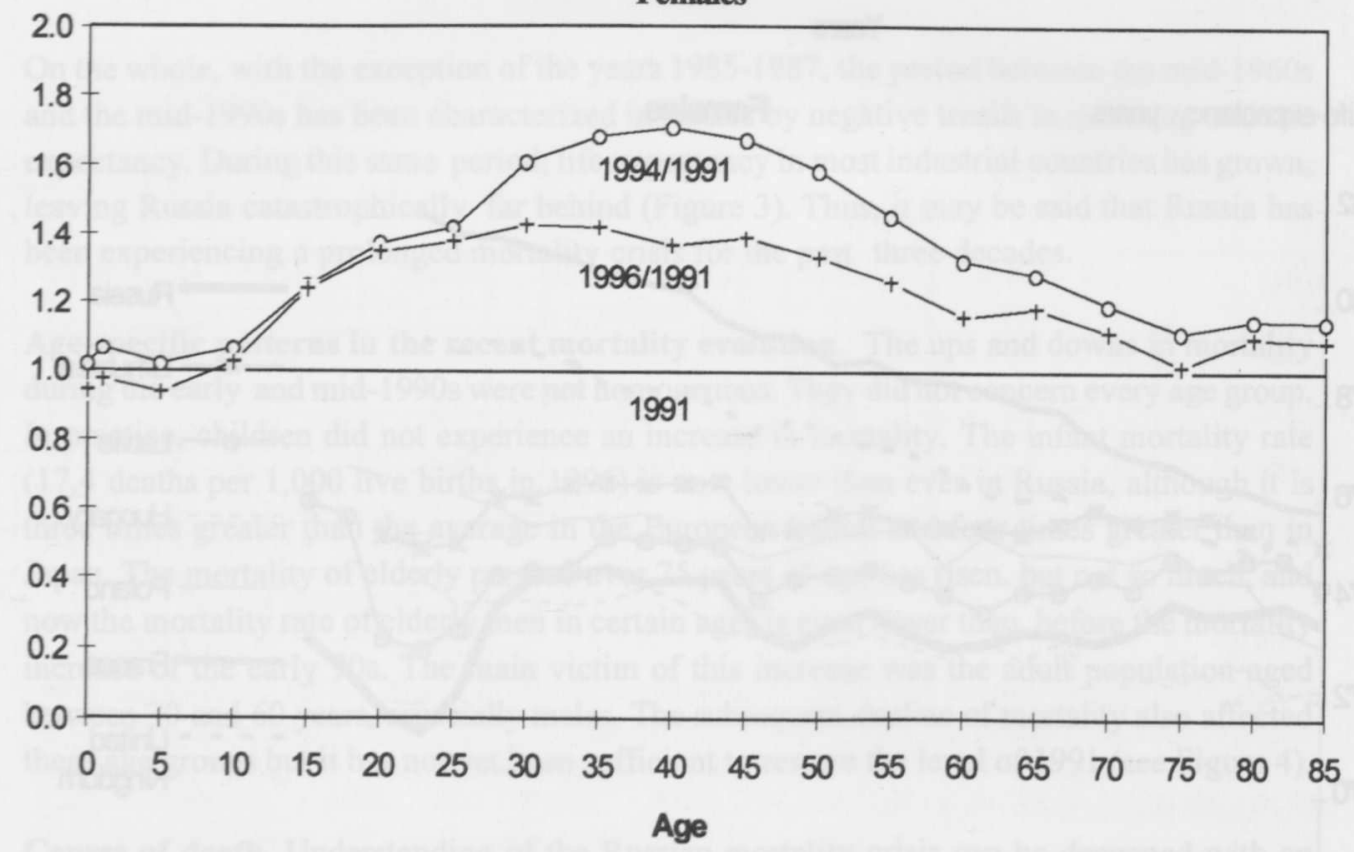

Source: Population of Russia 1997. 5th Annual Report. Centre for Demography and Human Ecology. Moscow, 1998, p. 91. 
The special features of the Russian mortality pattern become evident when we compare the age and causes of the death structure of Russian mortality with the corresponding structure in other industrial countries. This structure is aptly described by a two-dimensional distribution, defining, on the one hand, the distribution of the chances of dying from different causes or groups of causes, and, on the other hand, the distribution by the mean age at death of every cause or group of causes. Both parameters are taken from the tables of mortality by causes of death.

As it is easy to see from Table 4, both distributions are very different in Russia and in the "West" (a synthetic model based on the averaged data for four industrial countries: the USA, United Kingdom, France and Japan in 1989-1992).

Table 4. Chances of dying from different causes of death and mean age at death from these causes. Russia, 1995

\begin{tabular}{|c|c|c|c|c|}
\hline & \multicolumn{2}{|c|}{$\begin{array}{l}\text { Chances (per 1000) of dying from } \\
\text { given causes }\end{array}$} & \multicolumn{2}{|c|}{ Mean age at death, years } \\
\hline & Males & Females & Males & Females \\
\hline \multicolumn{5}{|c|}{ Infectious and parasitic diseases } \\
\hline Russia & 21 & 6 & 43.7 & 40.9 \\
\hline West & 14 & 12 & 66.9 & 77.0 \\
\hline \multicolumn{5}{|c|}{ Malignant neoplasms } \\
\hline Russia & 142 & 125 & 63.0 & 66.1 \\
\hline West & 277 & 213 & 72.5 & 74.6 \\
\hline \multicolumn{5}{|c|}{ Diseases of the circulatory system } \\
\hline Russia & 460 & 689 & 67.5 & 77.6 \\
\hline West & 404 & 476 & 77.3 & 83.9 \\
\hline \multicolumn{5}{|c|}{ Diseases of the respiratory system } \\
\hline Russia & 66 & 36 & 60.2 & 65.0 \\
\hline West & 117 & 108 & 80.1 & 84.4 \\
\hline \multicolumn{5}{|c|}{ External causes } \\
\hline Russia & 228 & 72 & 42.2 & 49.2 \\
\hline West & 63 & 40 & 54.2 & 68.8 \\
\hline
\end{tabular}

Source: Vishnevsky A., Shkolnikov V. Mortality in Russia; Main Risk Groups and Priorities of Action). Moscow, 1997, tables 12, 16, 20, 24, 27.

Russia stands out sharply against the background of the Western model by the relatively low chances of dying from cancer and diseases of the circulatory system and high chances of dying from cardiovascular disease and especially from external causes. As for mean age at death, the Russian indices for every cause of death are much poorer than Western ones. It should be emphasized that the dynamics of both indices in Russia during the last three decades was very unfavorable. 
Chances of dying from different causes: long-term trends. Changes in the chance of dying from large classes of causes of death were generally negative during the period under examination, although there were some positive upheavals. For example, a continuous decline in the probability of dying from "available" causes of death, such as infectious or respiratory diseases, was accompanied by a simultaneous increase in the probability of dying from diseases of the circulatory system - cause of death of a prevalent endogenous nature and a relatively high mean age at death. Only in the first half of the 1990 s were these positive trends reversed - the chances of dying from infectious or respiratory diseases began to grow and the chances of dying from diseases of the circulatory system to decline (Figure 5).

The most unfavorable trend has been an increase in the chances of dying from accidents, poisoning, injuries and violent causes of death ("external causes"). The general reduction of mortality in the mid-80s was accompanied by a brief decline in the probability of dying from external causes, but high chances of dying from these causes soon reappeared and even increased. The long-term increase in the probability of dying from external causes has been strong enough to outweigh most positive or neutral upheavals which took place and made the Russian profile of chances of dying from different causes particularly unfavorable.

Mean age at death: long-term trends. Changes in the mean age at death, the second major component of the structure of mortality, were even more disappointing than changes in the probabilities of death. Progressive, positive change consists of an increase in the mean age at death, namely in shifting deaths to older age groups. In Russia, between the 1960s and 1990s, there was no sign of serious increases in the mean age of death for any cause of death category. In fact, with the exception of a short-term rise during the second half of the $1980 \mathrm{~s}$, the prevalent tendency was a decline in the mean ages of death - a rejuvenation of mortality (Figure 6). This tendency most seriously affected diseases of the circulatory system which are the cause of death for approximately half of men and more than two-thirds of women.

Age- and cause-specific groups of risk. The mortality situation in Russia is not homogeneous. There is a limited number of risk groups which decisively determine the unfavorable trends of mortality and life expectancy. Based on the relationship between age and causes of death, a relatively small number of age- and cause-specific groups at excess risk was identified as being responsible for the greatest part of overall mortality. These groups were derived through comparisons between the life table death figures categorized by large classes of causes of death at different ages in Russia and the "West" (Tables 5 and 6). The difference between the number of deaths in Russia and the "West" represents the excess number of deaths in each group. In a special study of main groups of risk carried out in 1997², 240 fiveyear age- and causes of death-specific groups were considered, based on the combination of 15 age groups - from 0 to 70 years - and 16 causal groups.

In 1995 , the overall excess number of deaths for males in ages under 70 years was 385 per 1,000 deaths in all ages. Within that figure, $51.4 \%$ of all excess deaths related to 20 specific age-causal groups from a total of 240 . The main risk groups for males were $40-70$-year-olds with ischemic heart disease and 50-70-year-olds with cerebrovascular disease. These two

${ }^{2}$ Vishnevsky A., Shkolnikov V. Mortality in Russia: main risk groups and priorities of action. Moscow, 1997. 
Figure 5. Chances of dying from 7 large categories of causes of death. Russia, 1965-1995, number of probable deaths per 100,000 new-born

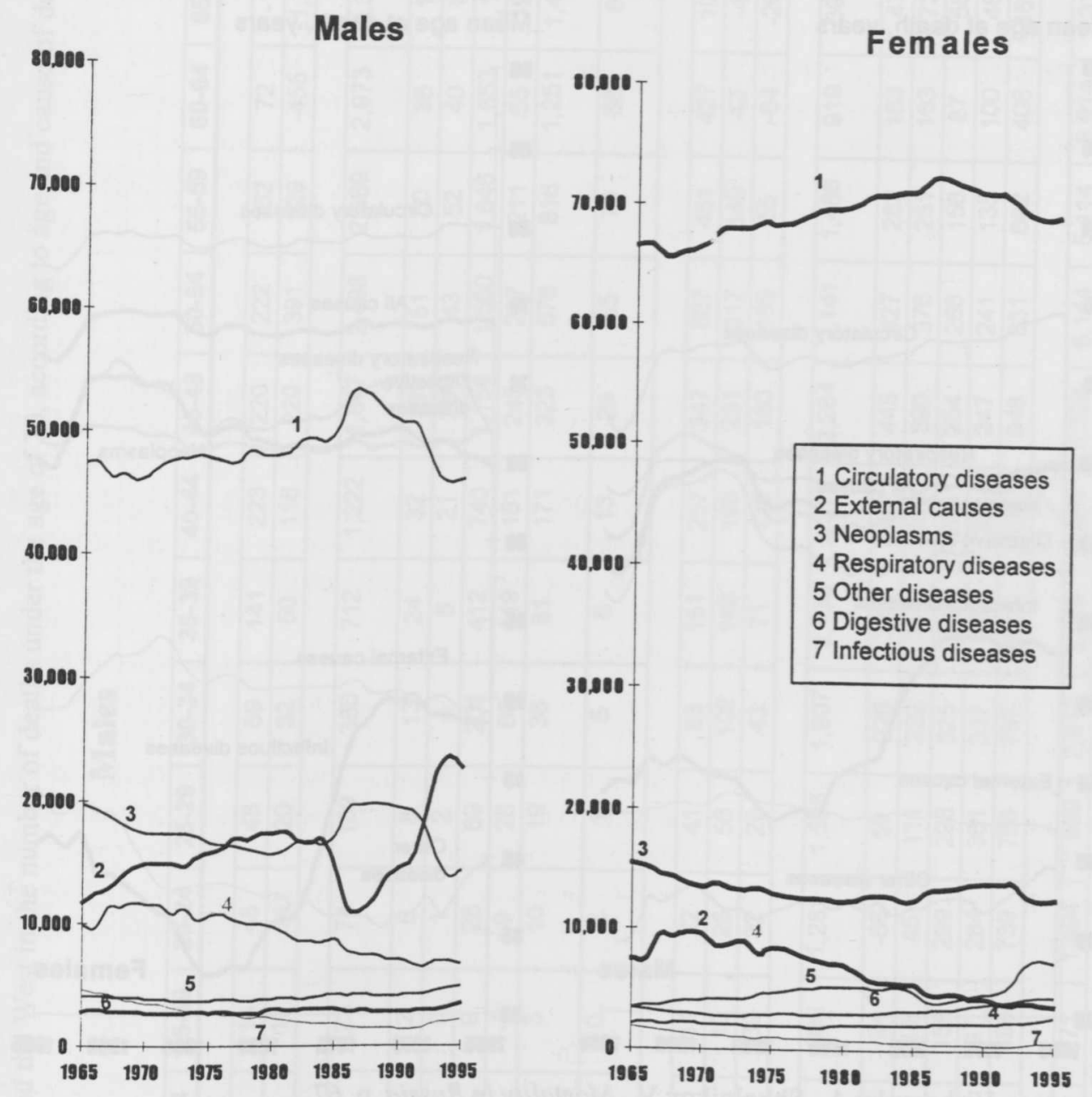

Source: Vishnevsky A., Shkolnikov V., Mortality in Russia, p. 66.

"risk zones" alone were responsible for $31.2 \%$ of all excess deaths in 1995 . The next highest risk came from external causes, which are responsible for almost $20 \%$ of all excess deaths. Beyond these two major "risk zones" there is a group of high mortality from "other diseases" for boys in their first year of life.

For females under 70 years old the excess number of deaths was much lower than for males, but it was also more concentrated. In 1995 the excess number of deaths for women was 174 per 1,000 deaths, of which $53.6 \%$ were concentrated in groups comprising less than $4 \%$ of the total number of groups. Indeed, one-third of all excess deaths for women were related to only four of the 240 age-causal groups.

The main risk groups for females were 55-70-year-olds with ischemic heart disease and cerebrovascular disease. In 1995 these groups were responsible for $42.1 \%$ of all excess female deaths. The impact of external causes on the excess mortality for females is much lower than for males and not so significant in comparison with the impact of the cardiovascular 
Figure 6. Mean age at death from 7 large categories of causes of death. Russia, 1965-1995

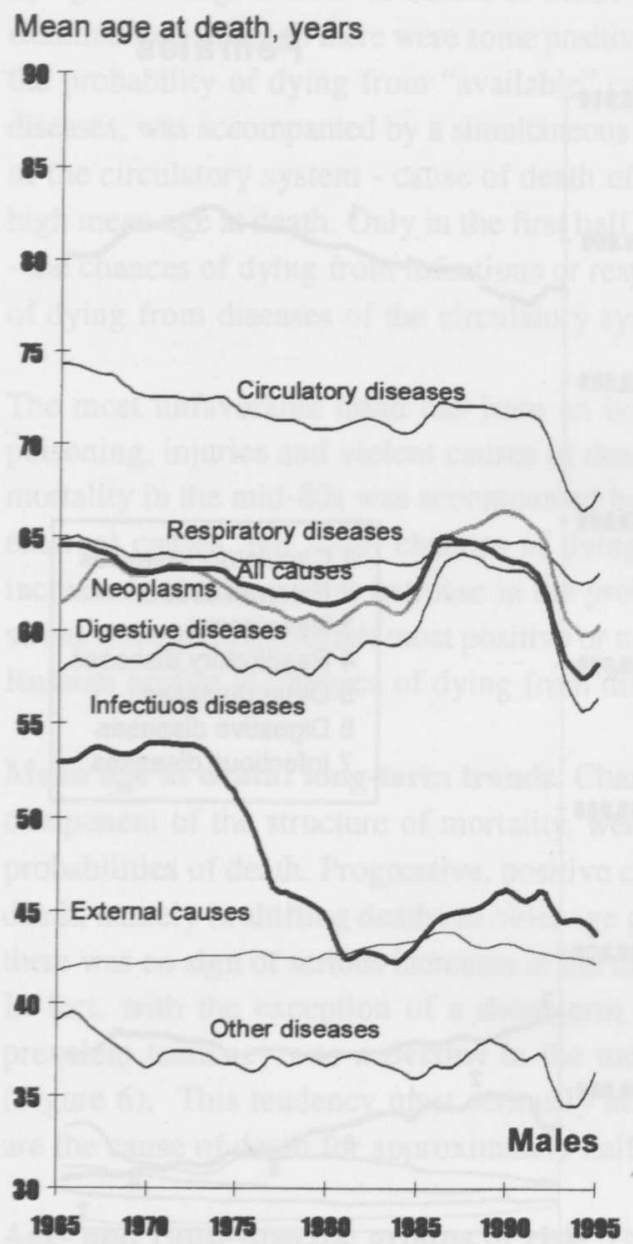

Mean age at death, years

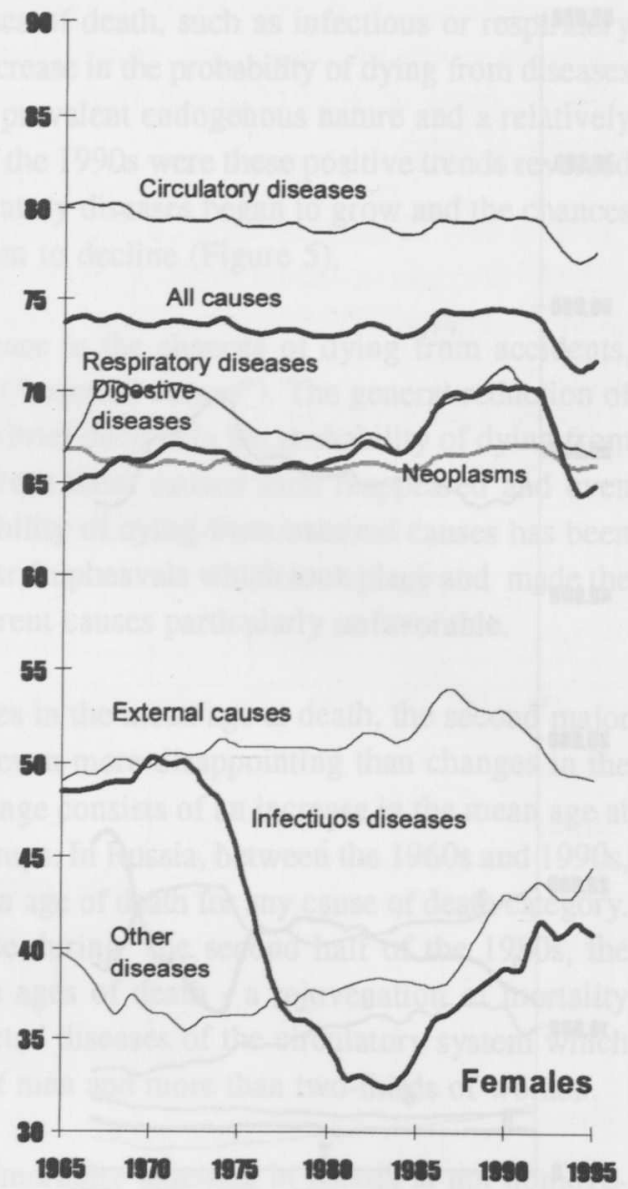

Source: Vishnevsky A., Shkolnikov V., Mortality in Russia, p. 67.

diseases. The number of infant deaths for girls from "other causes", is also very high, though lower than for boys. For both sexes, mortality from "other causes" is a major component of excess infant mortality and of infant mortality, in general (in 1995 it comprised $72 \%$ of all deaths under 1 year of age for boys and $70 \%$ for girls).

The knowledge of age- and cause-specific groups at excess risk is of more than theoretical interest. It is necessary to modify the current strategy of fighting against mortality and to make it more target-oriented. However, many other important determinants of population groups at risk are still unknown. The major social and sociocultural categories of the Russian population with the highest mortality as well as the socio-economic circumstances associated with excess deaths in these groups have not been sufficiently studied. This prevents the public health care system from effectively targeting efforts to lower the major part of excess Russian mortality and to overcome the long-term mortality crisis in Russia ${ }^{3}$.

${ }^{3}$ Not everybody is agree with such approach. According a Finnish expert of Russian Ministry of health, the role of the studies of mortality in the process of the evaluation of situation of public healtn system in Russia is "very doubtful". 


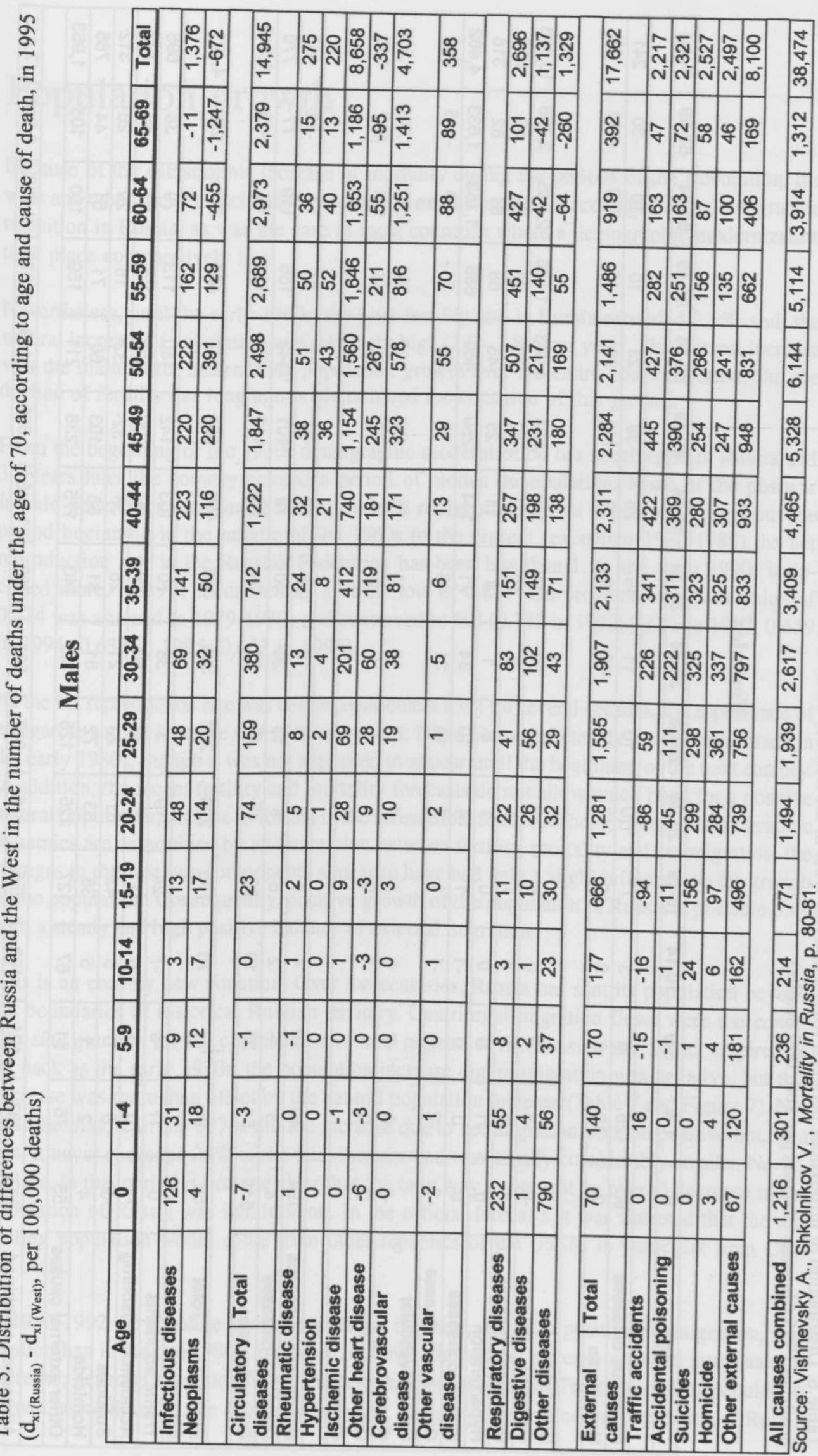




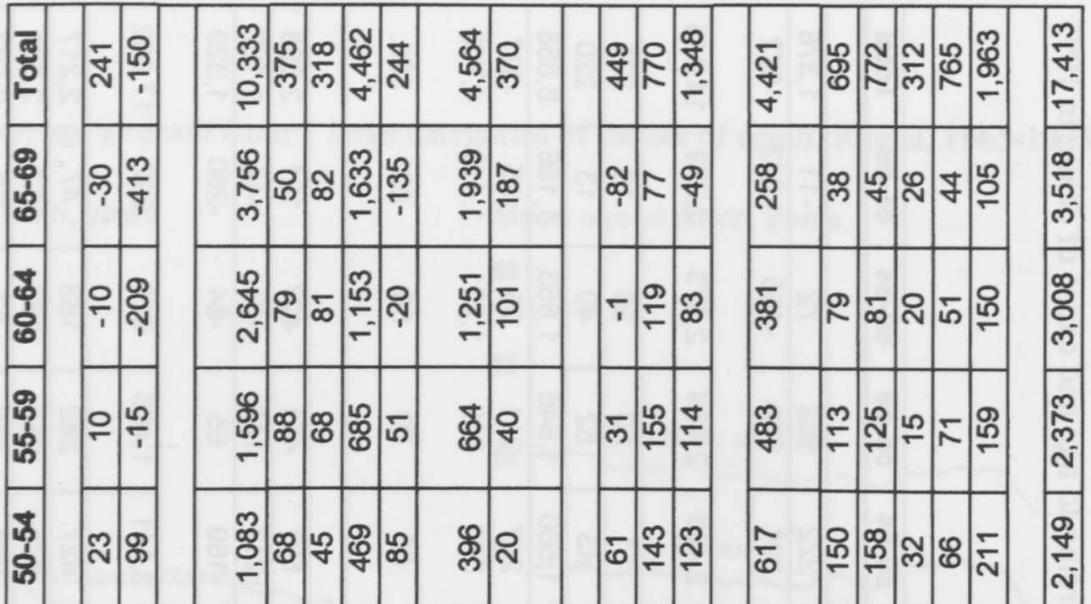

ग

尺

প্লে

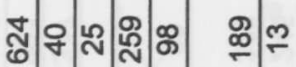

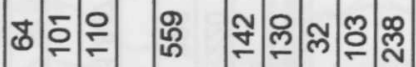

음

茨

品

$\stackrel{Ð}{\Xi}$

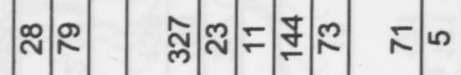

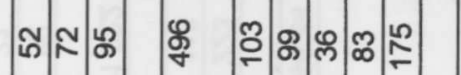

홈

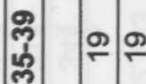

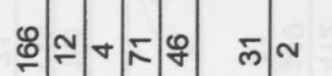

ผำำ

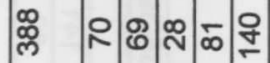

œ

营

क्षे

늘

สุ

$=$ 우

ஜம- ந্ল

$\dddot{\infty} \mathscr{N}$

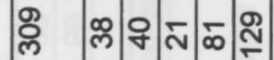

लू

ฝั่ 으

กิ $\nabla-\circ \cong \infty$

으의

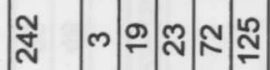

凩

సั่ 유

$\stackrel{\infty}{-}-\Delta \sim \Delta$

๑) $\infty$

ర్ల

$\frac{n}{m}$

政

产 $\sim 心$

$n-0 .-2$

๓

œ ホุー

央市

$\cong$

踝

ฮี

ㅎํ $m a$

0 m $0.7-\frac{1}{1}$

$\rightarrow$ ก

b r.

은

के ฮี

동ㅇㅇ

ติ 00

$$
\text { T- } 000 \text { ก0 }
$$

으- 유

i mol-

$\rightarrow$ 赵

ญ̊

\&

을

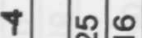

mo To T 00

守

ת NOON

ิㅏ:

这

- 8 N

ம)

ষே

$0 \div 0 \%$ บ

m

4

을

च

ํํำ

$0 . \Xi$

哭 


\section{Population growth}

Because of the catastrophic increase of mortality during the periods of the Revolution, the wars and other social cataclysms, a population explosion did not accompany the demographic transition in Russia, as was the case in most countries where a demographic modernization took place comparatively late.

Nevertheless, until the early 1960 s, the total fertility rate in Russia exceeded $2.5 \%$, and the natural increase of population was relatively high (1.7 - $1.8 \%$ per year). This natural increase was the main factor determining population growth over the entire postwar period. But the decline of fertility has long ago predetermined the cessation of this growth.

From the beginning of the 1930s demographic modernization has accelerated in Russia and 30 years later the country entered a period of hidden depopulation. None of the postwar female generations in Russia have provided replacement-level fertility. Throughout the period beginning in the middle of the 1960s to the present (excepting 1986-1988) the net reproduction rate in the Russian Federation has been less than 1. In the early 1990s it declined more. In 1991 it reached an all-time low of 0.821 (the previous minimum value of 0.874 was attained in 1979-1980) and continued to fall $(0.735$ in $1992 ; 0.651$ in $1993 ; 0,659$ in $1994 ; 0.633$ in $1995 ; 0,603$ in 1996).

As the net reproduction rate was below replacement level for several decades, the appearance of a negative natural increase was not unexpected. It had been predicted by the forecasts made in the early 1980s, though it was not supposed to appear until the beginning of the next century. In addition, the recent fertility and mortality forecasts do not allow much hope for a positive natural population increase in Russia in the foreseeable future. Although general demographic dynamics are determined by an interaction between fertility, mortality and net migration, the changes in the first two components appear to have had only a slight influence on the growth of the population. Consequently, positive growth of the population in Russia is possible only with a steady and high positive balance of external migration.

This is an entirely new situation. Over the centuries, Russia has sent its population beyond the boundaries of historical Russian territory. Centrifugal migration flows were the condition sine qua non for the colonization of new regions of the Russian and Soviet empire. As far back as the early 1970 s, the population increase due to migration was negative, but this decrease was more than offset by the natural population increase (Table 7 and Figure 7). Not until the middle of the 1970s did the increase due to net migration became positive but, as a rule, it never exceeded $25 \%$ of the total increase and was usually considerably smaller. Nevertheless, in this period it became clear that the only way to prevent an overall decrease in the population of Russia was immigration. In the official forecasts it was assumed that the migrating population would come from other republics of the USSR, in particular from Central Asia.

In 1990-1992 the absolute annual population increase, owing to positive net migration, was smaller than in the late 1980s and when, in 1992, the natural increase changed into a natural decrease, net migration alone was unable to compensate for it. The total rate of population growth, as well as the rate of natural increase, became negative and the population of Russia 
began to decrease. In succeeding years a sharp increase in net migration took place but the negative natural decrease was growing more rapidly and the population in Russia continued to decrease at an accelerated rate. By the beginning of 1998 the Russian population was reduced by 1.6 million.

Table 7. Population increase by components, 1951-1996

\begin{tabular}{|l|c|c|c|c|c|}
\hline & $\begin{array}{c}\text { Population at } \\
\text { the end of the } \\
\text { period, } \\
\text { thousands }\end{array}$ & $\begin{array}{c}\text { Annual rate of } \\
\text { increase, } \\
\text { per 1,000 }\end{array}$ & $\begin{array}{c}\text { General } \\
\text { increase, } \\
\text { thousands }\end{array}$ & $\begin{array}{c}\text { Natural } \\
\text { increase, } \\
\text { thousands }\end{array}$ & $\begin{array}{c}\text { Net migration, } \\
\text { thousands }\end{array}$ \\
\hline $1951-1955$ & 112266 & 17,5 & 9321 & 9160 & 161 \\
$1956-1960$ & 120766 & 14,7 & 8500 & 9515 & -1015 \\
$1961-1965$ & 127189 & 10,4 & 6423 & 7067 & -644 \\
$1966-1970$ & 130704 & 5,5 & 3515 & 4180 & -665 \\
$1971-1975$ & 134690 & 6,0 & 3986 & 4180 & -195 \\
$1976-1980$ & 139028 & 6,6 & 4338 & 3730 & 607 \\
$1981-1985$ & 143835 & 7,0 & 4807 & 3939 & 869 \\
$1986-1990$ & 148543 & 6,1 & 4707 & 3649 & 1058 \\
1991 & 148704 & 1,1 & 161 & 104 & 57 \\
1992 & 148673 & $-0,2$ & -31 & -207 & 176 \\
1993 & 148366 & $-2,1$ & -307 & -737 & 430 \\
1994 & 148306 & $-0,4$ & -60 & -870 & 810 \\
1995 & 147976 & $-2,2$ & -330 & -832 & 502 \\
1996 & 147502 & $-3,2$ & -474 & -818 & 344 \\
\hline
\end{tabular}

Figure 7. Population increase by components in Russia, 1959-1996, in thousands 2000

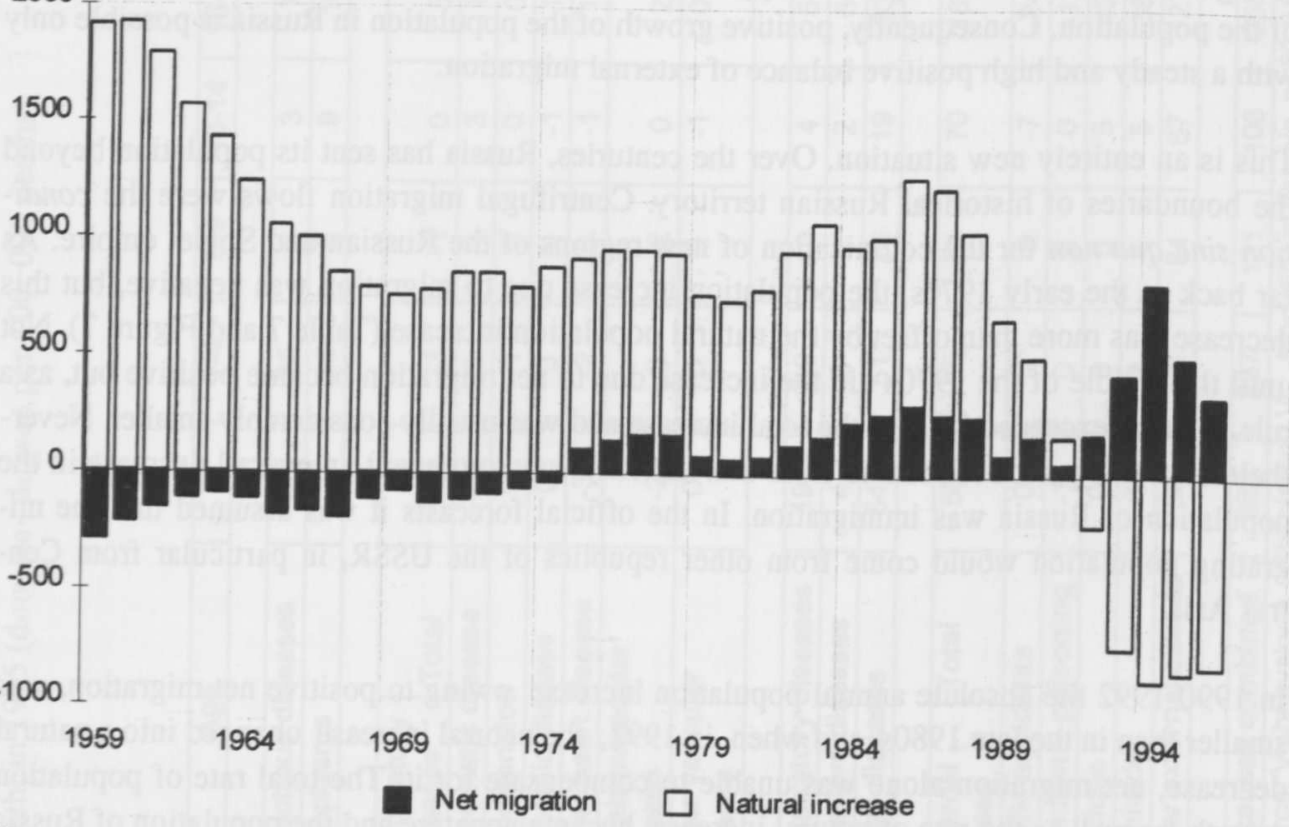

Source: Centre for Demography and Human Ecology; Population of Russia 1997, p. 8. 
What changes await Russia in the next 10-20 years? According to estimates made by the Centre for Demography and Human Ecology, assuming the most realistically optimistic scenarios for fertility and mortality along with annual net migration at a level of 0.3-0.4 million persons, by 2010 the Russian population will reach the level of the early 1990s, after a twentyyear period of decline. For the population size to exceed the 1990 level by the middle of the first decade of the 21 st century and continue to grow, one needs to assume high net migration, constantly maintained at a level of about half a million persons per year.

Table 8. Population of Russia according to different forecasts

\begin{tabular}{|l|c|c|c|c|c|}
\hline & $\mathbf{1 9 9 0}$ & $\mathbf{1 9 9 5}$ & $\mathbf{2 0 0 0}$ & $\mathbf{2 0 0 5}$ & $\mathbf{2 0 1 0}$ \\
\hline Goskomstat, 1997 & 148.0 & 147.9 & $144.1-145.9$ & $139.5-144.8$ & $134.7-143.7$ \\
UN, 1996 & 148.0 & 147.9 & $145.8-147.1$ & $142.8-146.0$ & $139.5-145.1$ \\
$\begin{array}{l}\text { US Bureau of the } \\
\text { Census, 1997 }\end{array}$ & 148.0 & 147.9 & 145.9 & 144.3 & 143.9 \\
\hline
\end{tabular}

Sources: Statistical bulletin, Goskomstat, Moscow, 1997, p. 7 ('Presumable size of the population of the Russian Federation up to 2010'); United Nations. World Population Prospects: the 1996 Revision; US Bureau of the Census International Data Base.

Are these hypotheses realistic? The answer to this question depends highly on the estimates of current trends of migration. In the early 1990s positive net immigration grew. In 1994, 1.1 million persons arrived in Russia (compared with 0.7-0.9 million annually during the previous 25 years) and 0.3 million left Russia (compared with $0.5-0.7$ million previously). So the net migration figure was about 0.8 million - an unusually high number for Russia. But after 1994 net migration diminished rapidly ( 0.5 million persons in 1995, 0.26 million in 1996). Public opinion in Russia is rather against immigration. According to the different scenarios of the official population prospects of Goskomstat (1997 Revision) net migration in 2010 will be 4-10 times smaller than in $1996^{4}$. What all this means is that a high level of net migration capable of maintaining growth or even the stability of the Russian population for the next ten years is unlikely. All population forecasts unanimously predict a further decrease of the Russian population.

\footnotetext{
4'Presumable size of the population in the Russian Federation until 2010'. Statistical bulletin. Moscow, Goskomstat, 1997, p. 101.
} 